\title{
Veronica officinalis Product Authentication Using DNA Metabarcoding and HPLC-MS Reveals Widespread Adulteration with Veronica chamaedrys
}

\begin{abstract}
Ancuta C. Raclariu1,2, Andrei Mocan 3,4, Madalina O. Popa', Laurian Vlase, Mihael C. Ichim ${ }^{2}$, Gianina Crisan ${ }^{3}$, Anne K. Brysting ${ }^{6}$ and Hugo de Boer ${ }^{1,7 *}$
\end{abstract}

\begin{abstract}
'Plant Evolution and Metabarcoding Group, Natural History Museum, University of Oslo, Oslo, Norway, ${ }^{2}$ Stejarul Research Centre for Biological Sciences, National Institute of Research and Development for Biological Sciences (NIRDBS), Piatra Neamt, Romania, ${ }^{3}$ Department of Pharmaceutical Botany, Faculty of Pharmacy, Iuliu Hatieganu University of Medicine and Pharmacy, Cluj-Napoca, Romania, ${ }^{4}$ ICHAT and Institute for Life Sciences, University of Agricultural Sciences and Veterinary Medicine of Cluj-Napoca, Cluj-Napoca, Romania, ${ }^{5}$ Department of Pharmaceutical Technology and Biopharmaceutics, Iuliu Hatieganu University of Medicine and Pharmacy, Cluj-Napoca, Romania, ${ }^{6}$ Department of Biosciences, Centre for Ecological and Evolutionary Synthesis (CEES), University of Oslo, Oslo, Norway, ${ }^{7}$ Department of Organismal Biology, Evolutionary Biology Centre, Uppsala University, Uppsala, Sweden
\end{abstract}

OPEN ACCESS

Edited by:

Atanas G. Atanasov,

Institute of Genetics and Animal Breeding (PAN), Poland

Reviewed by:

Marcello Locatelli,

Università degli Studi "G. d'Annunzio"

Chieti - Pescara, Italy

C. Haris Saslis-Lagoudakis, Natural History Museum of Denmark,

Denmark

*Correspondence: Hugo de Boer hugo.deboer@nhm.uio.no

Specialty section: This article was submitted to

Ethnopharmacology,

a section of the journal

Frontiers in Pharmacology

Received: 23 April 2017

Accepted: 31 May 2017

Published: 19 June 2017

Citation

Raclariu AC, Mocan A, Popa MO,

Vlase L, Ichim MC, Crisan G, Brysting AK and de Boer H (2017) Veronica officinalis Product Authentication Using DNA Metabarcoding and HPLC-MS Reveals Widespread Adulteration with Veronica chamaedrys.

Front. Pharmacol. 8:378. doi: 10.3389/fphar.2017.00378
Studying herbal products derived from local and traditional knowledge and their value chains is one of the main challenges in ethnopharmacology. The majority of these products have a long history of use, but non-harmonized trade and differences in regulatory policies between countries impact their value chains and lead to concerns over product efficacy, safety and quality. Veronica officinalis L. (common speedwell), a member of Plantaginaceae family, has a long history of use in European traditional medicine, mainly in central eastern Europe and the Balkans. However, no specified control tests are available either to establish the quality of derived herbal products or for the discrimination of its most common substitute, $V$. chamaedrys L. (germander speedwell). In this study, we use DNA metabarcoding and high performance liquid chromatography coupled with mass spectrometry (HPLC-MS) to authenticate sixteen $V$. officinalis herbal products and compare the potential of the two approaches to detect substitution, adulteration and the use of unreported constituents. HPLC-MS showed high resolution in detecting phytochemical target compounds, but did not enable detection of specific plant species in the products. DNA metabarcoding detected $V$. officinalis in only $15 \%$ of the products, whereas it detected $V$. chamaedrys in $62 \%$ of the products. The results confirm that DNA metabarcoding can be used to test for the presence of Veronica species, and detect substitution and/or admixture of other Veronica species, as well as simultaneously detect all other species present. Our results confirm that none of the herbal products contained exactly the species listed on the label, and all included substitutes, contaminants or fillers. This study highlights the need for authentication of raw herbals along the value chain of these products. An integrative methodology can assess both the quality of herbal products in terms of target compound concentrations and species composition, as well as admixture and substitution with other chemical compounds and plants.

Keywords: adulteration, DNA metabarcoding, herbal products, HPLC-MS, Veronica chamaedrys, Veronica officinalis 


\section{INTRODUCTION}

Traditional herbal medicines play an important role in meeting healthcare needs around the world, and complementary and alternative medicines based on these are gaining in importance in many industrialized countries as a perceived healthy alternative to synthetic pharmaceuticals (World Health Organization, 2013). The commercialization of such products is undergoing a transition process from unregulated locally traded products to internationally traded mass produced herbal pharmaceuticals and food supplements (Heinrich, 2010; Leonti and Casu, 2013). A challenge in ethnopharmacology is to study such novel herbal products and their value chains (Heinrich, 2010; Atanasov et al., 2015), as these are impacted by nonharmonized regulatory and trade policies (Booker et al., 2012, 2016).

The regulation of herbal products varies globally and between EU member countries, these falling under specific legislation depending on their intended use, for instance, as food, food supplements, herbal medicines, or homeopathic products. Similar to the United States and Canada, the EU currently does not have a centralized marketing authorization procedure for herbal products, but instead provides relevant methodological specifications to guarantee manufacturing quality. The EU also lacks a central public institution for pharmacovigilance of the herbal products, and the primary legal responsibility for safety of the marketed herbal products is delegated to the pharmaceutical industry, whereas national pharmacovigilance agencies monitor drug safety.

A lack of standards for studies of medicinal plants has been previously identified (cf. Ríos and Recio, 2005; Gertsch, 2009) and several authors have advocated a stronger guidance of value chains to mitigate this shortcoming (Rios et al., 1988; Cos et al., 2006; Verpoorte, 2008). Current quality assessment methods rely mainly on morphology and analytical chemistry based methods detailed in national or EU pharmacopoeias (EDQM - Council of Europe, 2014). However, the resolution of these methods is highly influenced by factors such as the phenotypic plasticity, morphological cryptic taxa, species-specific chemical markers, growing conditions, harvesting process, storage condition, or the extraction procedure (Barnes, 2003; Bickford et al., 2007; Jiang et al., 2010; Shaw et al., 2012).

In addition to ensuring that herbal products contain the intended ingredients in the right quantities, an important problem is the use of substitutes and undeclared fillers (Coghlan et al., 2012, 2015; Newmaster et al., 2013). Misidentification (Saslis-Lagoudakis et al., 2015) or incongruences in the vernacular names of the raw material (Farah et al., 2006; Ouarghidi et al., 2012; Walker and Applequist, 2012; De Boer et al., 2015) can lead to accidental substitution, but rising prices of raw materials and the high demand for such products also provide an incentive for deliberate adulteration. The use of unlabelled ingredients presents a serious safety challenge as adverse drug reactions cannot be associated to the product label and ingredients (Heubl, 2010; Gilbert, 2011). Recent studies of herbal medicine and herbal food supplement value chains using a combination of phytochemical and metabolomics analyses have found that adulteration of these products often occurs in the first stages of their value chains (Booker et al., 2012, 2014, 2016).

Veronica officinalis L. (common speedwell) is a popular medicinal plant in several European countries, especially in central eastern Europe and the Balkans, and used in herbal medicine both traditionally and increasingly in commercial herbal products. Veronica L. (Plantaginaceae) is a genus of about 450 species (Albach and Meudt, 2010) occurring over most of the Northern Hemisphere and in many parts of the Southern Hemisphere (Mabberley, 2008). Modern systematic studies of the genus have focused on molecular phylogenies of several nuclear and plastid markers: the nuclear ribosomal internal transcribed spacer, nrITS (Wagstaff and Garnock-Jones, 1998; Albach and Chase, 2001; Albach et al., 2004; Buhk et al., 2015), the plastid regions trnL-F (Albach et al., 2004, 2006; Buhk et al., 2015), ndhF-rpl32 (Sonibare et al., 2014; Albach and Al-Gharaibeh, 2015; Buhk et al., 2015), trnH-psbA (Sonibare et al., 2014; Albach and AlGharaibeh, 2015), rps16 intron (Albach and Chase, 2004), rps16-trnK (Sonibare et al., 2014; Albach and Al-Gharaibeh, 2015).

\section{Ethnopharmacological Importance of Veronica Species}

Several Veronica species are used in European traditional medicine to treat respiratory affections, as an expectorant, an antiscorbutic, a diuretic, and for wound healing (Baytop, 1984; Harput et al., 2002a). In Turkey, the aerial parts of Veronica anagallis-aquatica L. are boiled in milk to obtain a poultice used to alleviate abdominal pain (Küpeli et al., 2005), or used as a bath cure to relieve rheumatic pain (Fujita et al., 1995). In the Valdesi valley of Italy, in the poorer villages Veronica species are traditionally used as an inexpensive substitute for imported teas and this has been posed as an explanation of the modern use of Veronica species in recreational teas (Bellia and Pieroni, 2015). In traditional Chinese medicine $V$. anagallis-aquatica is used for the treatment of influenza, hemoptysis, laryngopharyngitis, and hernia (Su et al., 1999). In Europe, V. officinalis is the best-known and most commonly used species (Table 1). The main ethnopharmacological indications for $V$. officinalis are inflammatory conditions, rheumatism, stomach ulcers, respiratory ailments (Scarlat et al., 1985; Mocan et al., 2015b), and nervous, cardiovascular and metabolism system disorders (Vogl et al., 2013).

\section{Phytochemical and Pharmacological Studies}

Veronica species are rich in iridoid glucosides, mainly aucubin, catalpol and benzoic and cinnamic acid esters of catalpol, all compounds that have previously been investigated for their bioactivities (Harput et al., 2002a,b, 2014; Saracoglu et al., 2002). Saracoglu and Harput (2012) showed that some iridoid glucosides of $V$. anagallis-aquatica, $V$. persica Poir, and $V$. thymoides P.H.Davis subsp. pseudocinerea M.A.Fisch. exhibited cytostatic 
TABLE 1 | Traditional uses of Veronica officinalis in different European countries.

\begin{tabular}{|c|c|c|}
\hline Country & Use & Reference \\
\hline Austria & $\begin{array}{l}\text { Cardiovascular system } \\
\text { Metabolism } \\
\text { Nervous system } \\
\text { Respiratory tract }\end{array}$ & Vogl et al., 2013 \\
\hline Bulgaria & $\begin{array}{l}\text { Appetizer } \\
\text { Anti-inflammatory } \\
\text { Antitussive } \\
\text { Asthma } \\
\text { Coughs } \\
\text { Expectorant } \\
\text { Pharyngitis } \\
\text { Tonsillitis }\end{array}$ & $\begin{array}{l}\text { Ivancheva and Stantcheva, } \\
\text { 2000; Leporatti and Ivancheva, } \\
2003\end{array}$ \\
\hline Italy & Recreational tea & Bellia and Pieroni, 2015 \\
\hline Montenegro & $\begin{array}{l}\text { Bronchitis } \\
\text { Rheumatic complaints } \\
\text { Skin diseases } \\
\text { Wounds }\end{array}$ & Menković et al., 2011 \\
\hline Romania & $\begin{array}{l}\text { Antiulcerous activity } \\
\text { Catarrh } \\
\text { Cough } \\
\text { Hepatoprotective activity } \\
\text { Hypocholesterolemic effect } \\
\text { Kidney diseases } \\
\text { Lung diseases } \\
\text { Wound healing properties }\end{array}$ & $\begin{array}{l}\text { Tamas et al., 1984; Scarlat } \\
\text { et al., 1985; Crişan et al., 2007; } \\
\text { Gründemann et al., } 2013\end{array}$ \\
\hline Serbia & $\begin{array}{l}\text { Against anemia } \\
\text { Hypolipemic } \\
\text { Treatment of skin diseases }\end{array}$ & Zlatković et al., 2014 \\
\hline Sweden & Recreational tea & Sõukand et al., 2013 \\
\hline
\end{tabular}

and cytotoxic activities on human and murine cancer cell lines, with verminoside being the most cytotoxic compound and Harput et al. (2002a) showed that V. cymbalaria Bodard, $V$. hederifolia L., V. pectinata L. var. glandulosa, V. persica and $V$. polita Fr. possess anti-inflammatory, cytotoxic and radical scavenging activities. Vogl et al. (2013) showed for the first time in vitro anti-inflammatory activity of the extracts prepared from $V$. officinalis. Nikolova (2011) found that $V$. bellidioides L., V. kellereri Degen \& Urum., V. vindobonensis (M.A.Fisch.) M.A.Fisch., V. beccabunga L., $V$. rhodopea Degen ex Stoj. $\&$ Stef. and $V$. austriaca L. showed significant antioxidant properties.

\section{Quality Issues of Veronica officinalis Herbal Products}

As a folk remedy, $V$. officinalis is used mostly in traditional medicine, and no current national pharmacopeia monographs include standards for quality control or authentication of Veronica herbal products. Identification tests currently available to detect substitutes and adulterants rely on chromatographic methods, usually as a combination of separate approaches (e.g., HPLC with TLC-densitometry) or a combination of different approaches into a single procedure (e.g., HPLC-UV, HPLC-MS or GC-MC) (European Medicine Agency [EMA], 2006; EDQM Council of Europe, 2014).

All raw materials of $V$. officinalis used in the marketed herbal products are harvested from the spontaneous flora, and sourced from several countries in central eastern Europe and the Balkans. Kathe et al. (2003) and Ichim et al. (2011) cite that the exploitation pressure of wild-harvesting could potentially threaten the species. The limited availability of $V$. officinalis is a likely driver behind the widespread substitution with $V$. chamaedrys L. (germander speedwell), an abundant herb of grassland and forest edges, with no proven therapeutic uses Crişan et al. (2007, 2011). Furthermore, even though their vegetative morphology is clearly distinct, the flowers of $V$. officinalis and $V$. chamaedrys can easily be confused (Leyel, 1937). Crişan et al. (2001, 2011) report histological, anatomical and phytochemical characters that distinguish $V$. officinalis and $V$. chamaedrys and propose a rapid differentiation method using thin-layer chromatography (TLC) of species-specific phenyl-propanoic compounds. These analytical methods enable chemical identification of some target compounds, but cannot rule out that other Veronica species, or mixtures thereof, might be present in the investigated products. Marketed herbal products are complex formulations that are usually highly processed and consist of numerous ingredients.

\section{DNA Barcoding and Metabarcoding}

Rapid advances in DNA sequencing have enabled cost-effective use of DNA sequences for species identification. Hebert et al. (2003) coined the concept of DNA barcoding as a rapid and accurate way of species-level identifications using short standard DNA regions. Different combinations of plastid markers (e.g., rbcL, matK, and trnH-psbA) and the nuclear ribosomal internal transcribed spacer (nrITS) have been proposed as the primary barcodes for plants, and the current core barcodes are rbcL and matK, supplemented by nrITS (Kress and Erickson, 2007; CBOL Plant Working Group, 2009; China Plant BOL Group, 2011; Hollingsworth et al., 2011). Several studies have shown that about $75-85 \%$, and in some floras over $90 \%$, of plant species can be identified to species level using DNA barcoding (Lahaye et al., 2008; Kress et al., 2009, 2010; Chen et al., 2010; Burgess et al., 2011). In taxonomically difficult plant groups, where hybridization is frequent, or in lineages of relatively young age the use of traditional barcodes may not be reliable (Kress and Erickson, 2007; Fazekas et al., 2009). In such groups the use of low-coverage shotgun sequencing of genomic DNA could resolve relationships and augment current plant barcodes (Coissac et al., 2016; Hollingsworth et al., 2016).

Techen et al. (2014) reviewed the progress made in DNA barcoding of medicinal plants. DNA barcoding of herbal products has revealed alarming levels of substitution within marketed herbal products, for instance, $6 \%$ in saw palmetto herbal dietary supplements (Little and Jeanson, 2013), 16\% in ginkgo products (Little, 2014), 25\% in black cohosh (Baker et al., 2012), $33 \%$ in herbal teas (Stoeckle et al., 2011), 50\% in ginseng (Wallace et al., 2012), 37\% in Senna and 50\% in Cassia market products (Seethapathy et al., 2014). Newmaster et al. (2013) 
tested 44 herbal products sold in North America using DNA barcoding and found that 59\% contained species not listed on the label, and only 2 out of 12 screened companies had products free of substitution, contamination or unreported fillers. DNA metabarcoding, a combination of high-throughput sequencing (HTS) and polymerase chain reaction based DNA amplification, provides simultaneous taxonomic identification of taxa from samples containing DNA from different origins (Taberlet et al., 2012). DNA metabarcoding studies are providing insights into species composition of complex mixtures of DNA such as processed herbal products. For example, Coghlan et al. (2012) evaluated the species composition of fifteen highly processed traditional Chinese medicines (TCM) and found that these contained species and genera included on CITES appendices I and II. Similarly, Cheng et al. (2014) found a high level of contamination within 27 investigated herbal preparations, Ivanova et al. (2016) found that all 15 tested herbal supplements contained species not listed on the product label, and Raclariu et al. (2017) authenticated 78 Hypericum perforatum herbal products and found the target species in only $68 \%$ products while detecting incongruence between constituent species and those listed on the label in all products.

In this study we test the hypothesis that dwindling availability of wild $V$. officinalis has resulted in admixture of $V$. chamaedrys and other Veronica species in Veronica herbal products. Substitution of $V$. officinalis with $V$. chamaedrys would not only be fraudulent from a commercial perspective, but would also leave anticipating consumers with a herbal product without proven therapeutic activity. We approach this hypothesis using DNA metabarcoding and HPLC-MS to authenticate and detect species diversity in European Veronica herbal products, and aim to answer the following research questions: (1) Can HPLC-MS be used to distinguish $V$. officinalis from $V$. chamaedrys and to identify exclusive presence of $V$. officinalis in herbal products?; (2) Can DNA metabarcoding be used to test for the presence of $V$. officinalis in herbal products, to detect substitution and adulteration for other Veronica species and/or presence of other off label plant species?

\section{MATERIALS AND METHODS}

\section{Sample Collection}

Sixteen single and multi-ingredient herbal products including $V$. officinalis on the label were purchased from retail stores and pharmacies (14) and via e-commerce (2). The products included herbal teas (12), extracts (2), capsules (1), and candies (1). An overview of the samples is included in the Supplementary Table S1, but identifying information on the producer/importer, product name, lot number, expiration date is withheld for anonymity. The herbal products were imported to Norway under Norwegian Medicines Agency license no. 16/04551-2.

For DNA barcoding, nrITS reference sequences of 118 accessions belonging to 56 Veronica species were compiled into a barcode reference database, consisting partly of sequences mined from NCBI/GenBank and partly of sequences generated within the project from specimens collected in 2014 and 2015 (Supplementary Table S2). For the phytochemical analyses, aerial parts of $V$. officinalis and $V$. chamaedrys (samples marked with an asterisk in Supplementary Table S2) were used as references for the identification and quantification of the main compounds. Voucher specimens of the plant material used in this study are deposited in the Herbarium of the Alexandru Borza Botanical Garden (CL) of Babes-Bolyai University, Cluj-Napoca, Romania (Supplementary Table S2).

\section{Phytochemical Analysis High-Performance Liquid Chromatography-Mass Spectrometry (HPLC-MS)}

Extracts were prepared from plant material and herbal products following established procedures (Crişan et al., 2010; Mocan et al., 2015a,b), with slight modifications. One gram of each sample was extracted with $10 \mathrm{ml}$ of $70 \%$ ethanol (HPLC grade) at room temperature for $1 \mathrm{~h}$ in a sonication bath (Polsonic 3, Polsonic Inc., Poland). The extracts were filtered through MN 615 filter paper (Macherey-Nagel $\mathrm{GmbH}$, Germany) and stored at $4^{\circ} \mathrm{C}$ until further analysis. Prior to HPLC-MS analysis the extracts were syringe filtered with a $0.45 \mu \mathrm{m}$ nylon membrane (Whatman Inc., United States).

Target Veronica iridoids (aucubin, catalpol, catalposide, and veronicoside) from all sixteen herbal products as well as aerial plant parts were analyzed by HPLC-MS on a Agilent 1100 liquid chromatography system equipped with a binary pump, autosampler, thermostat and detector (all 1100 Series from Agilent Inc., United States). The system was controlled with Data Analysis software (version B01.03, Agilent Inc., United States). The separation was carried out on an Atlantis HILIC $3.5 \mu \mathrm{m}(100 \mathrm{~mm} \times 3.0 \mathrm{~mm}$ i.d.) (Waters Inc., United States) column equipped with an online $0.2 \mu \mathrm{m}$ filter (Agilent Inc.), at a working temperature of $40^{\circ} \mathrm{C}$, a flow rate of $0.75 \mathrm{ml} / \mathrm{min}$ and an injection volume of $6 \mu \mathrm{l}$. A binary gradient system with eluent (A) $0.1 \%$ acetic acid and $20 \mu \mathrm{M}$ sodium acetate in water, and eluent (B) $0.1 \%$ acetic acid and $20 \mu \mathrm{M}$ sodium acetate in acetonitrile was used for the analyzed samples with the following gradient: $95-80 \%$ B (1$5 \mathrm{~min})$. The HPLC system was coupled with an Agilent Ion Trap 1100 SL mass spectrometer equipped with an electrospray ionisation (ESI) source and operated in the positive mode with a scan range between 360 and $680 \mathrm{~m} / \mathrm{z}$, to identify the target compounds based on their sodium adducts $(M+23 \mathrm{~m} / \mathrm{z})$ : aucubin $(369 \mathrm{~m} / \mathrm{z})$, catalpol $(385 \mathrm{~m} / \mathrm{z})$, catalposide $(505 \mathrm{~m} / \mathrm{z})$ and veronicoside $(489 \mathrm{~m} / \mathrm{z})$, and by comparison with analytical standards in the same chromatographic conditions. The capillary voltage was set to $4 \mathrm{kV}$ and the capillary temperature to $325^{\circ} \mathrm{C}$. Nitrogen $\left(\mathrm{N}_{2}\right)$ was used as dry gas with a dry flow of $12 \mathrm{l} / \mathrm{min}$ and a pressure of $60 \mathrm{psi}$ for the nebulizer. For quantitation of the iridoids, stock solutions of the four commercially available standards substances (Sigma-Aldrich, St. Louis, Missouri, United States) were prepared in acetonitrile, and different concentrations of each standard were used. All calibration curves yielded a coefficient of determination of 
$R^{2} \geq 0.99$. The results are expressed as $\mu \mathrm{g}$ per $\mathrm{g}$ of dry weight material $(\mu \mathrm{g} / \mathrm{g} \mathrm{dw})$.

\section{Genetic Analysis DNA Extraction, PCR Amplification and DNA Sequencing}

The total DNA was extracted from $300 \mathrm{mg}$ of each homogenized herbal product or silica gel dried leaves, using a modified CTAB extraction protocol (Doyle and Doyle, 1987; Kool et al., 2012). Two extraction negative controls were included to screen for contamination and cross-contamination. Total DNA extracts of the herbal products were quantified and assessed for fragmentation with a Fragment Analyzer (Advanced Analytical Technologies, Inc., Ankeny, IA, United States) using the DNF488-33 HS (High Sensitivity) genomic DNA Reagent Kit (50 $40000 \mathrm{bp}$ ). Total DNA extracts of silica gel dried leaves were quantified with a Qubit 2.0 fluorometer (Life Technologies, Carlsbad, CA, United States) using the dsDNA BR (BroadRange) kit. PCR amplification using nrITS primers, ITS-4 and ITS-5 (White et al., 1990), was done on purified total DNA from the dried leaves, using a final reaction volume of $25 \mu \mathrm{l}$, including $2.5 \mu \mathrm{l} 10 \mathrm{X}$ reaction buffer II (supplied with the polymerase), $2.5 \mu \mathrm{l} 25 \mathrm{mM} \mathrm{MgCl} 2$ (supplied with the polymerase), $0.2 \mu 15 \mathrm{U} / \mathrm{ml}$ AmpliTaq DNA Polymerase (Applied Biosystems, Foster City, CA, United States), $2.5 \mu 110 \mu \mathrm{M}$ dNTPs (Applied Biosystems, Foster City, CA, United States), $2.5 \mu 1$ $10 \mu \mathrm{M}$ of each primer (Sigma-Aldrich, St. Louis, Mo, United States), $2.5 \mu l 1 \mathrm{mg} / \mathrm{ml}$ bovine serum albumen (BSA) (Roche Diagnostic GmbH, Mannheim, Germany), $9.3 \mu \mathrm{l}$ of Milli-Q ultrapure water and $0.5 \mu \mathrm{l}$ of template DNA solution $(1 \mathrm{ng} / \mu \mathrm{l})$. The PCR cycling protocol consisted of initial denaturation at $94^{\circ} \mathrm{C}$ for $2.5 \mathrm{~min}$, followed by 32 cycles of denaturation at $94^{\circ} \mathrm{C}$ for $30 \mathrm{~s}$, annealing at $53^{\circ} \mathrm{C}$ for $30 \mathrm{~s}$, and elongation at $72^{\circ} \mathrm{C}$ for $50 \mathrm{~s}$, followed by a final elongation step at $72^{\circ} \mathrm{C}$ for $4 \mathrm{~min}$. Three PCR negative controls were included per amplification to control for external and cross-sample contamination. $6 \mu \mathrm{l}$ of each PCR products was purified using $2 \mu 110$ times diluted ExoSAP-IT (USB Corporation, Cleveland, OH, United States) by incubation at $37^{\circ} \mathrm{C}$ for $45 \mathrm{~min}$ followed by $15 \mathrm{~min}$ at $80^{\circ} \mathrm{C}$. Sequencing was performed using the ABI BigDye Terminator sequencing buffer and the v3.1 Cycle Sequencing kit (Applied Biosystems, Foster City, CA, United States) on an ABI3130XL automated sequencer (Applied Biosystems, Foster City, CA, United States). The sequences were edited, and the forward and reverse sequences assembled using SeqTrace (Stucky, 2012). The sequences were submitted to NCBI/GenBank and their accession numbers are listed in the Supplementary Table S2.

\section{Barcode Gap Analysis}

The reference sequences of 118 accessions belonging to 56 Veronica species were aligned using AliView (Larsson, 2014), and pairwise genetic distances between the accessions were calculated using MEGA 6.0 (Tamura et al., 2013) for each of the following regions: nrITS1, nrITS2, and the entire nrITS. Automatic Barcode Gap Discovery (ABGD) (Puillandre et al., 2012) was used to determine the genetic distance threshold and automatically define species delimitation hypotheses. ABGD determines the number of groups (hypothetical species) within a dataset using pairwise sequence distances and two input variables, prior intraspecific diversity $(P)$ and minimum gap width $(X)$ (Puillandre et al., 2012). Based on this information ABGD makes an initial partition of the supplied sequences into candidate species groups based on a statistically inferred barcode gap and then applies recursive partitions to each group to generate subsequent partitions into candidate species until no further splitting occurs (Puillandre et al., 2012). The minimum gap width $(X)$ was set to $X=1.0$, the prior intraspecific diversity $(P)$ was set to range from 0.001 to 0.1 , and the $p$-distance, JukesCantor (JC) and Kimura 2 Parameter (K2P) distance metrics were used in the ABGD analyses (Jukes and Cantor, 1969; Kimura, 1980), resulting in 18 analyses (6 per dataset). Default values were used for all other parameters (steps: 10 and Nb bins: 20). The total numbers of groups corresponding to the prior intraspecific divergence $(P)$ values, ranging from 0.001 to 0.1 , were recorded (Supplementary Table S3).

To determine whether $V$. officinalis can be unambiguously differentiated from its main adulterant, $V$. chamaedrys, using molecular operational taxonomic units (MOTUs), the intra- and interspecific variation of all reference sequences of these species, respectively, 16 accessions belonging to $V$. officinalis and 9 to $V$. chamaedrys, were analyzed based on pairwise comparison of nrITS genetic distances using Taxon DNA/SpeciesIdentifier v 1.7.8 (Meier et al., 2006).

\section{DNA Metabarcoding}

Fusion primers of the internal transcribed spacers nrITS1 and nrITS2, based on primers 17SE and 5.8I1, and 5.8I2 and 26SE (Sun et al., 1994) (Biolegio B.V., the Netherlands), were used to generate PCR based amplicons. Forward primers were fused with a unique $10 \mathrm{bp}$ multiplex identifier (MID) tags and the reverse primers with a truncated version of adapter P1 (trP1) tags. Expected amplicon sizes were 300-350 bp. PCR reactions on DNA extracted from the herbal products were carried out in final reaction volumes of $25 \mu \mathrm{l}$ including $0.5 \mu \mathrm{l}$ of template DNA solution (ranging from 0.5 to $2 \mathrm{ng} / \mu \mathrm{l}$ ), $5 \mu \mathrm{l} 5 \mathrm{X}$ Q5 reaction buffer (New England Biolabs Inc., United Kingdom), $1.5 \mu 110 \mu \mathrm{M}$ of each primer (Biolegio B.V., the Netherlands), $0.5 \mu \mathrm{l} 10 \mathrm{mM}$ dNTPs, $0.25 \mu \mathrm{l} 20 \mathrm{U} / \mu \mathrm{l}$ Q5 High-Fidelity DNA Polymerase (New England Biolabs Inc., United Kingdom), $5 \mu \mathrm{l}$ 5X Q5 High GC enhancer and $10.75 \mu$ l of Milli-Q ultrapure water. The PCR cycling protocol consisted of initial denaturation at $98^{\circ} \mathrm{C}$ for 30 s, followed by 35 cycles of denaturation at $98^{\circ} \mathrm{C}$ for 10 s, annealing at $56^{\circ} \mathrm{C}$ for nrITS1 or $71^{\circ} \mathrm{C}$ for nrITS2 for $30 \mathrm{~s}$, and elongation at $72^{\circ} \mathrm{C}$ for $30 \mathrm{~s}$, followed by a final elongation step at $72^{\circ} \mathrm{C}$ for $2 \mathrm{~min}$. Eight PCR negative controls were included per amplification to control for external and crosssample contamination.

Agencourt AMPure XP PCR purification (Beckman Coulter Inc., United States) was used for high-throughput purification of PCR amplicons. The size, purity and the molar concentration $(\mathrm{nmol} / \mathrm{l})$ of each amplicon library was measured using a Fragment Analyzer ${ }^{\mathrm{TM}}$ (Advanced Analytical Technologies Inc., United States) with a DNF-910 dsDNA Reagent Kit (35$1,500 \mathrm{bp}$ ), equimolar pools ( $2 \mathrm{ng} / \mu \mathrm{l} / \mathrm{library})$ were prepared 
from the amplicon libraries using a Biomek 4000 Laboratory Automation Workstation (Beckman Coulter Inc., United States). To identify the optimum bead-to-template ratio for template preparation, the concentration of the purified pooled amplicon libraries was analyzed with a Fragment Analyzer ${ }^{\mathrm{TM}}$ (Advanced Analytical Technologies, Inc., United States) using a DNF-488 High Sensitivity Genomic DNA Analysis Kit. The pooled Ion AmpliSeq libraries (Life Technologies, Thermo Fisher Scientific Inc., United States) for emulsion PCR and sequencing chip loading were prepared using an Ion Chef (LT). The DNA template concentration was adjusted to the number of Ion Sphere Particles (ISPs) and added to the emulsion PCR master mix. The templatepositive ISPs were enriched and sequenced on an Ion Torrent Personal Genome Machine (LT) using Ion 318 v2 chips (LT) and the Ion PGM Sequencing 400 kit (LT). Sequencing read data was initially processed and demultiplexed based on MIDs into FASTQ files using Ion Torrent Suite Software version 5.0.4 (LT).

\section{Bioinformatics Analysis}

Sequencing reads were processed using the HTS barcode-checker pipeline freely available at https:/github.com/naturalis/HTSbarcode-checker (Lammers et al., 2014). The nrITS1 and nrITS2 primer sequences were used to split the reads based on the primer sequence. Read lengths and Phred quality scores were assessed using PRINSEQ (Schmieder and Edwards, 2011), and based on these values reads with a mean Phred quality score of less than 26 and a length of less than 300 bp were filtered out. The remaining reads were trimmed to a maximum length of $350 \mathrm{bp}$. Reads were clustered into MOTUs using three different sequence similarity thresholds during clustering, respectively, 97, 99 and $100 \%$, with a minimum of 10 reads per cluster using CDHIT-EST (Li and Godzik, 2006). A representative sequence from each MOTU was taxonomically assigned using local Basic Local Alignment Search Tool (local BLAST) (Altschul et al., 1990), with a maximum e-value of 0.05 and a minimum hit length of $100 \mathrm{bp}$, against a reference database consisting of a local copy of the NCBI nucleotide database (Benson et al., 2013). Species level identifications were assigned when similarity to the reference barcode matched at $>99 \%$.

\section{RESULTS AND DISCUSSION}

\section{Phyotochemical Analysis High-Performance Liquid Chromatography-Mass Spectrometry (HPLC-MS)}

Iridoids and iridoid glycosides are specific chemotaxonomic markers for the genus Veronica, and most Veronica species contain the iridoid glycosides aucubin and/or catalpol as well as one or more 6-O-esters of catalpol (i.e., veronicoside, catalposide) (Afifi-Yazar and Sticher, 1980; Taskova et al., 2002, 2004; Jensen et al., 2005). The main known ethnopharmacological indication for Veronica species are inflammatory diseases (rheumatism, stomach ulcer) or respiratory ailments (Scarlat et al., 1985; Mocan et al., 2015a), and several studies have shown that iridoid glycosides in Veronica are linked to this therapeutic effects (Scarlat et al., 1985; Gründemann et al., 2013; Ignjatović,
2015). Although regulatory guidelines to establish quality control or authentication of Veronica herbal products are lacking, the presence and concentration of specific iridoid glycosides has been shown to enable authentication of Veronica herbal products (Crişan et al., 2010; Gründemann et al., 2013).

The HPLC-MS results from the present study show the characterization of Veronica herbal products against four commercially available iridoid glycosides, namely aucubin, catalpol, veronicoside and catalposide (Table 2). The two most commonly identified compounds in the examined herbal products and reference plant material were aucubin and catalpol. From a pharmaceutical point of view, the concentrations of the compounds present in different herbal remedies or plant materials cannot be neglected as they are directly linked to their pharmaceutical efficacy and effectiveness. Aucubin was found in fifteen herbal products samples as well as in the reference plant material of both species ( $V$. officinalis and $V$. chamaedrys), with the highest concentration in sample 9. Aucubin concentrations in the herbal products and reference plant material show a large variation with concentrations ranging from 0.33 to $39.73 \mu \mathrm{g} / \mathrm{g}$. Catalpol was found in 13 herbal products, with the highest concentration in sample 11, but was missing in two of the reference plant samples ( $V$. off 4 and $V$. cha 1). No iridoid glycosides were identified in sample 14, a lozenge with nineteen ingredients listed on the label. Jensen et al. (2005) concludes that aucubin and/or catalpol is/are present in all Veronica species, implying that if sample 14 contains any material of Veronica this would be below the level of detection of the HPLC-MS platform we used in this study, and consequently unlikely to exert any pharmacological activity. Concerning the other two 6-O-esters of catalpol, veronicoside was present in five herbal products and in all $V$. officinalis reference material, with highest concentration in sample $V$. off 1, while catalposide was present in nine herbal products, with the highest concentration in sample 8 , but none of the investigated reference plant materials contained catalposide. Jensen et al. (2005) states that although aucubin and/or catalpol are present in all Veronica species, $V$. micrantha is the only species in Veronica subgenus Chamaedrys, to which $V$. chamaedrys belongs, that contains aucubin. However, this assumption was later rejected by Crişan et al. (2010) that identified both aucubin and catalpol in $V$. chamaedrys, and as well as by the results of this study.

\section{Genetic Analyses Barcode Gap Analysis}

Species-level identification using DNA barcoding and metabarcoding requires that the level of intraspecific genetic divergence is lower than the interspecific genetic divergence (Meyer and Paulay, 2005), and several identification approaches are based on setting a cut-off threshold above which a query sequence is considered to be distinct from a reference sequence. Defining an optimal threshold is a controversial debate (Hebert et al., 2004; Meyer and Paulay, 2005; Smith et al., 2005; Wiemers and Fiedler, 2007; Chen et al., 2013). Previous studies proposed different thresholds of genetic distances, for instance, $1 \%$ (Ratnasingham and Hebert, 2013), 3\% (Smith et al., 2005) or the 


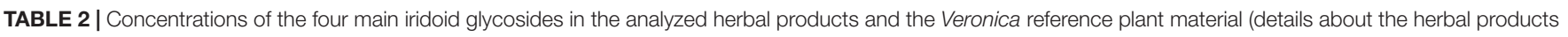
can be found in Supplementary Table S1).

\begin{tabular}{|c|c|c|c|c|}
\hline \multirow[t]{2}{*}{ Product no. } & \multicolumn{4}{|c|}{ Concentrations (in $\mu \mathrm{g} / \mathrm{g}$ ) } \\
\hline & Veronicoside & Catalposide & Aucubin & Catalpol \\
\hline 1 & $n / c$ & $0.48 \pm 0.02$ & $1.19 \pm 0.03$ & $0.28 \pm 0.01$ \\
\hline 2 & $n / c$ & $\mathrm{n} / \mathrm{c}$ & $1.58 \pm 0.02$ & $1.05 \pm 0.04$ \\
\hline 3 & $\mathrm{n} / \mathrm{c}$ & $3.38 \pm 0.11$ & $13.77 \pm 0.52$ & $1.52 \pm 0.04$ \\
\hline 4 & $0.24 \pm 0.01$ & $2.10 \pm 0.08$ & $29.17 \pm 1.03$ & $5.42 \pm 0.18$ \\
\hline 5 & $\mathrm{n} / \mathrm{c}$ & $\mathrm{n} / \mathrm{c}$ & $0.33 \pm 0.01$ & $0.56 \pm 0.02$ \\
\hline 6 & $\mathrm{n} / \mathrm{c}$ & $\mathrm{n} / \mathrm{c}$ & $20.79 \pm 0.73$ & $\mathrm{n} / \mathrm{c}$ \\
\hline 7 & $\mathrm{n} / \mathrm{c}$ & $\mathrm{n} / \mathrm{c}$ & $6.01 \pm 0.13$ & $\mathrm{n} / \mathrm{c}$ \\
\hline 8 & $\mathrm{n} / \mathrm{c}$ & $4.56 \pm 0.16$ & $18.24 \pm 0.71$ & $5.82 \pm 0.12$ \\
\hline 9 & $\mathrm{n} / \mathrm{c}$ & $0.22 \pm 0.01$ & $39.73 \pm 1.17$ & $2.33 \pm 0.09$ \\
\hline 10 & $\mathrm{n} / \mathrm{c}$ & $\mathrm{n} / \mathrm{c}$ & $26.88 \pm 0.95$ & $3.97 \pm 0.13$ \\
\hline 11 & $8.81 \pm 0.39$ & $0.77 \pm 0.02$ & $11.78 \pm 0.43$ & $11.46 \pm 0.37$ \\
\hline 12 & $9.06 \pm 0.41$ & $2.01 \pm 0.08$ & $7.31 \pm 0.29$ & $9.63 \pm 0.38$ \\
\hline 13 & $2.74 \pm 0.11$ & $2.08 \pm 0.07$ & $4.16 \pm 0.17$ & $1.92 \pm 0.08$ \\
\hline 14 & $\mathrm{n} / \mathrm{c}$ & $\mathrm{n} / \mathrm{c}$ & $\mathrm{n} / \mathrm{c}$ & $\mathrm{n} / \mathrm{c}$ \\
\hline 15 & $\mathrm{n} / \mathrm{c}$ & $\mathrm{n} / \mathrm{c}$ & $0.64 \pm 0.02$ & $0.43 \pm 0.01$ \\
\hline 16 & $1.01 \pm 0.03$ & $0.37 \pm 0.01$ & $1.11 \pm 0.04$ & $1.12 \pm 0.02$ \\
\hline V. off 1 & $36.07 \pm 1.8$ & $\mathrm{n} / \mathrm{c}$ & $11.32 \pm 0.55$ & $10.04 \pm 0.45$ \\
\hline V. off 2 & $0.29 \pm 0.01$ & $\mathrm{n} / \mathrm{c}$ & $1.94 \pm 0.07$ & $3.32 \pm 0.15$ \\
\hline V. off 3 & $1.72 \pm 0.03$ & $\mathrm{n} / \mathrm{c}$ & $1.53 \pm 0.06$ & $0.48 \pm 0.01$ \\
\hline V. off 4 & $0.27 \pm 0.01$ & $\mathrm{n} / \mathrm{c}$ & $0.41 \pm 0.02$ & $\mathrm{n} / \mathrm{c}$ \\
\hline V. cha 1 & $\mathrm{n} / \mathrm{c}$ & $\mathrm{n} / \mathrm{c}$ & $3.39 \pm 0.11$ & $\mathrm{n} / \mathrm{c}$ \\
\hline V. cha 2 & $n / c$ & $\mathrm{n} / \mathrm{c}$ & $6.12 \pm 0.29$ & $0.87 \pm 0.03$ \\
\hline V. cha 3 & $n / c$ & $\mathrm{n} / \mathrm{c}$ & $7.44 \pm 0.32$ & $0.93 \pm 0.02$ \\
\hline V. cha 4 & $n / c$ & $\mathrm{n} / \mathrm{c}$ & $7.52 \pm 0.27$ & $2.38 \pm 0.10$ \\
\hline
\end{tabular}

$10 \mathrm{X}$ rule where the interspecific distances are considered to be 10 times greater than intraspecific distances (Hebert et al., 2004), but each has shortcomings for general application (Meier et al., 2008; Rach et al., 2008; Bertolazzi et al., 2009).

In this study we used ABGD to assess the 'barcode gap' for the Veronica genus, with the specific aim of evaluating if nrITS has sufficient discriminatory power to differentiate $V$. officinalis from its main adulterant, $V$. chamaedrys. The three distance metrics used for the analyses produced identical initial partitions within each dataset and for all the values of prior intraspecific diversity $(P)$, but with a slight difference between the datasets, respectively, 14 groups for nrITS and nrITS2 and 13 for nrITS1. The recursive partitions resulted in a variable number of groups within each dataset depending on $P$, respectively, with 18,22, 37, and 53 groups for nrITS dataset, 14, 19, and 37 groups for nrITS1, and $16,23,31$, and 54 groups for nrITS2 data set.

Infra- and interspecific divergence based on pairwise comparison of nrITS genetic distances of $V$. officinalis and $V$. chamaedrys (Supplementary Table S4) helped to identify an optimal clustering threshold for analysis of high-throughput sequence data and accurate molecular identification and discrimination of the two species. Pairwise intraspecific genetic distances did not exceed 1.5\%, and furthermore $93.8 \%$ of the pairwise intraspecific distances were below 1\%. Pairwise interspecific genetic distances, on the other hand, ranged from 18 to $22 \%$. The pairwise comparisons showed that applying
97\% or more similarity as a clustering threshold will confidently discriminate $V$. officinalis and $V$. chamaedrys. These results are consistent with the ABGD analysis in which the sequences belonging to $V$. officinalis and $V$. chamaedrys were assigned to well defined independent groups using an a priori defined genetic threshold of $1 \%$.

\section{DNA Metabarcoding}

The quantity of the total DNA extracted from the sixteen herbal products varied between samples. Total DNA concentration measurement gave detectable results for 15 of the samples (93.7\%), with DNA concentrations ranging from 0.06 to $87.32 \mathrm{ng} / \mu \mathrm{l}$, and nrITS1 and nrITS2 amplicons were obtained for all these samples. One sample, marketed as a lozenge, did not yield a measurable DNA concentration and no amplicons of nrITS1 and nrITS2 were obtained from this sample (Supplementary Table S5).

The raw data before demultiplexing consisted of 2,638,101 sequences, with an average of 82,440 sequences per sample for each marker. Sequencing was successful for thirteen herbal products $(81.3 \%)$ for both nrITS1 and nrITS2 and they were used for further analysis (Table 3). Three products, two herbal teas $(5,16)$ and the lozenge $(14)$, did not yield reads or MOTUs after applying the quality filtering criteria and were excluded from further analyses. A total of 63,929 sequences passed our trimming and filtering quality criteria (2.4\% of reads), including 19,788 
TABLE 3 | Overview of the results of three clustering thresholds (97, 99, and 100\%).

\begin{tabular}{|c|c|c|c|c|c|c|c|c|c|}
\hline \multirow[t]{2}{*}{ Sample \# } & \multirow{2}{*}{$\begin{array}{l}\text { nrITS1+nrITS2 \# reads } \\
\text { before demultiplexing }\end{array}$} & \multirow{2}{*}{$\begin{array}{l}\text { nrlTS21 \# } \\
\text { reads }\end{array}$} & \multirow{2}{*}{$\begin{array}{l}\text { nrlTS2 \# } \\
\text { reads }\end{array}$} & \multicolumn{2}{|c|}{$97 \%$} & \multicolumn{2}{|c|}{$99 \%$} & \multicolumn{2}{|c|}{$100 \%$} \\
\hline & & & & \# MOTUs & \# Species & \# MOTUs & \# Species & \# MOTUs & \# Species \\
\hline 1 & 163443 & 80255 & 78683 & 15 & 6 & 75 & 11 & 108 & 12 \\
\hline 2 & 180106 & 104096 & 67500 & 17 & 11 & 71 & 17 & 79 & 16 \\
\hline 3 & 158877 & 85618 & 69168 & 19 & 7 & 53 & 13 & 188 & 12 \\
\hline 4 & 440956 & 299997 & 114335 & 47 & 12 & 142 & 23 & 191 & 16 \\
\hline $5^{*}$ & 34 & 8 & 18 & 0 & 0 & 0 & 0 & 0 & 0 \\
\hline 6 & 217323 & 131223 & 74700 & 16 & 7 & 27 & 7 & 47 & 7 \\
\hline 7 & 400607 & 174347 & 192110 & 49 & 25 & 99 & 32 & 191 & 26 \\
\hline 8 & 309978 & 73352 & 213401 & 30 & 16 & 107 & 23 & 303 & 19 \\
\hline 9 & 80179 & 58175 & 16627 & 25 & 14 & 36 & 13 & 49 & 12 \\
\hline 10 & 62198 & 45321 & 15903 & 12 & 5 & 47 & 7 & 49 & 4 \\
\hline 11 & 254965 & 186423 & 47991 & 33 & 14 & 64 & 16 & 77 & 10 \\
\hline 12 & 122393 & 63939 & 55331 & 14 & 7 & 33 & 5 & 108 & 4 \\
\hline 13 & 26001 & 16464 & 7830 & 0 & 0 & 4 & 2 & 12 & 2 \\
\hline $14^{*}$ & 19 & 10 & 6 & 0 & 0 & 0 & 0 & 0 & 0 \\
\hline 15 & 220984 & 70947 & 131918 & 10 & 4 & 66 & 4 & 170 & 4 \\
\hline $16^{*}$ & 38 & 12 & 18 & 0 & 0 & 0 & 0 & 0 & 0 \\
\hline Total & 2638101 & 1390187 & 1085539 & 287 & 91 & 824 & 109 & 1572 & 80 \\
\hline
\end{tabular}

* Samples excluded from subsequent data analysis.

nrITS1 reads and 44,141 nrITS2 reads (Supplementary Table S6). The metabarcoding data is used for qualitative evaluation only, to determine presence of identified taxa, and not for quantitative assessment of relative species abundance based on read numbers, as too many variables impact the values, such as the availability of DNA that can be removed or degraded during the harvesting, drying, storage, transportation and processing (Bombardelli, 1991; Novak et al., 2007), as well as variation in nrITS copy numbers, primer annealing and PCR amplification biases (Pawluczyk et al., 2015). Furthermore, incomplete reference databases and incorrectly identified sequences in GenBank can impact taxonomic assignments.

The choice of similarity clustering thresholds $(>97,>99$, and $100 \%$ ) impacted the number and size of assigned MOTUs (Table 3). Setting the clustering threshold to $100 \%$ yielded 1572 MOTUs, $99 \%$ yielded 824 MOTUs, and $97 \%$ yielded only 287 MOTUs. The low number of MOTUs obtained using the $97 \%$ clustering threshold is likely the result of multiple species being grouped together into the same MOTU as 3\% divergence far exceeds interspecific variation in many genera (Yang and Rannala, 2017). Setting the clustering threshold to $100 \%$, on the other hand, likely resulted in more than one MOTU being formed for a single taxonomic species as a result of infraspecific variation and/or sequencing errors between reads. Here we followed previous studies in using a 99\% clustering threshold (Ghorbani et al., 2016; Raclariu et al., 2017; Veldman et al., 2017). Furthermore, to limit the impact of sequencing errors, which are known to affect the Ion Torrent sequencing platform (Loman et al., 2012; Salipante et al., 2014) and which could lead to the formation of false MOTUs, we used only the clusters that contained a minimum 10 reads.
The 824 MOTUs that were retained using a 99\% similarity clustering threshold were further identified using BLAST as 109 different species (Table 3 and Supplementary Table S6). Based on only nrITS1 we detected a total of 64 different species and on only nrITS2 61 species (Supplementary Table S6). Based on both markers, the number of species detected per sample ranged from 2 to 32 , with an average of 8 species per sample. Only two of the seven (28.6\%) single ingredient samples (those listing $V$. officinalis as the only ingredient) contained $V$. officinalis, three others contained $V$. chamaedrys and one contained other Veronica species, and all products contained additional species, ranging from 1 to 21 species per product. None of the nine retained multiple ingredient samples (i.e., those listing $V$. officinalis and other species on the label) contained only the listed ingredients, and none contained $V$. officinalis (Figure 1). The overall ingredient fidelity (detected species from product label/total number of species on label) was $9.5 \%$ for the multiple ingredient products, and $17 \%$ for all products. The target species $V$. officinalis was detected in only 2 products (15\%), whereas $V$. chamaedrys was detected in eight $(62 \%)$ of the retained samples. These results are supported by the pairwise comparison of the genetic distances that showed that $V$. officinalis could be unambiguously differentiated from $V$. chamaedrys using standard arbitrary clustering thresholds (Supplementary Table S4). In sample 10 a mixture of several Veronica species was detected, including $V$. bombycina Boiss. \& Kotschy, V. filiformis Sm., V. pectinata, V. tenuifolia Asso, $V$. krumovii (Peev) Peev and V. chamaedrys. The presence of these species can be explained as substitutes, admixtures or contaminants. It should be noted that the general monograph number 1433 on 'Herbal drugs' of the European Pharmacopoeia 

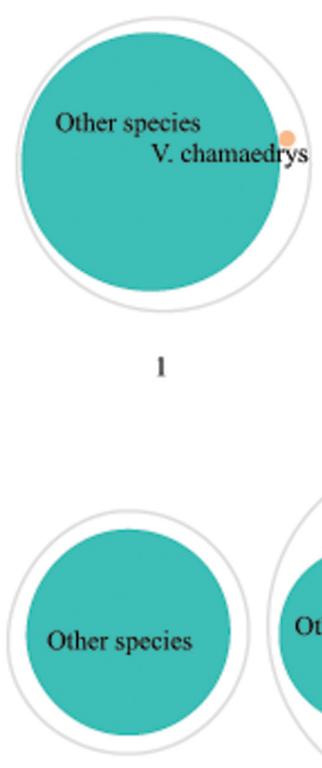

6

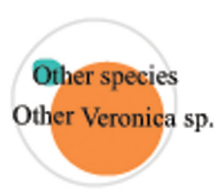

10

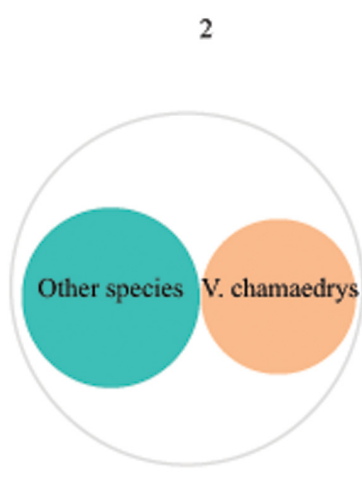

7

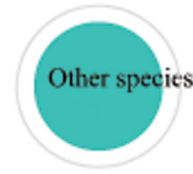

11
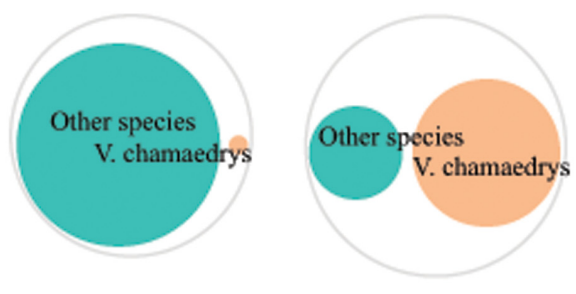

Other species V. chamaedrys

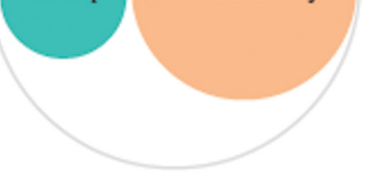

4

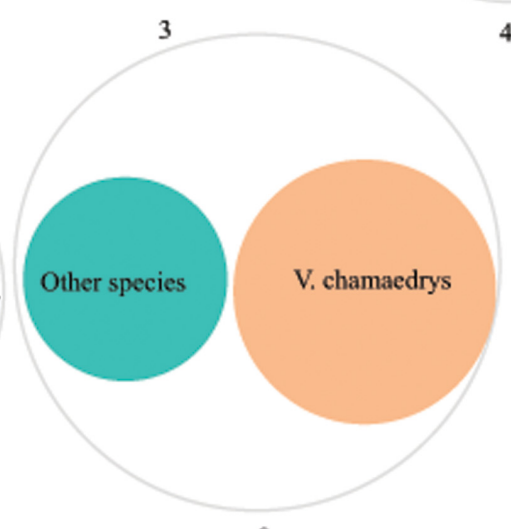

8

9

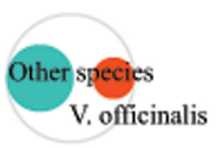

12

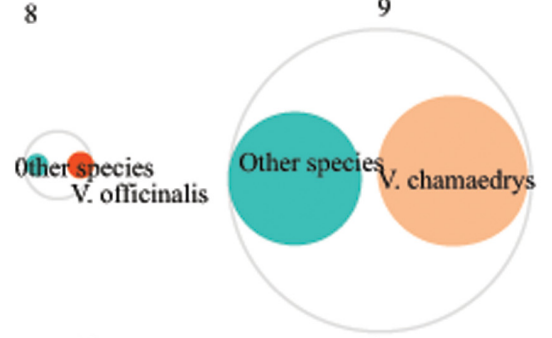

15

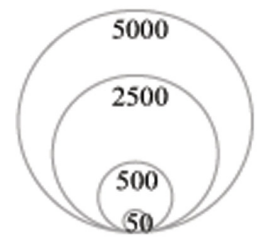

FIGURE 1 | Veronica and other species detected in the herbal products using DNA metabarcoding. Each numbered circle represents a product (more information about these products can be found in Supplementary Table S1). The size of circles corresponds to the relative abundance of the reads.

allows up to $2 \%$ foreign matter, unless this is differently indicated in a specific herb monograph (EDQM - Council of Europe, 2014). Presence of these other Veronica species might not be in breach of the European Pharmacopoeia but it does indicate a lapse in the value chain of this product. The same applies to the $62 \%$ products that contained $V$. chamaedrys instead of V. officinalis.

\section{CONCLUSION}

This study used HPLC-MS and DNA metabarcoding to authenticate and detect adulteration or admixture of $V$. officinalis with $V$. chamaedrys in Veronica herbal products. HPLC-MS is useful for qualitative and quantitative analysis of constituents in medicinal plants and herbal products and its use has increased in recent years (Steinmann and Ganzera, 2011; Bansal et al., 2014), but constraints are the expensive chemical reference standards (some of which are still unavailable for biologically active target components), sensitivity to the type of raw material and manufacturing process, and lack of resolution in distinguishing plant species (Bansal et al., 2014). Our HPLC-MS results show that distinction of $V$. officinalis from other Veronica species based on the targeted iridoid glycosides, aucubin, catalpol, veronicoside, and catalposide is difficult in pure products, and impossible in multiple ingredient products. General application 
of HPLC-MS to detect substitution and/or adulteration of highly processed and multi-ingredient herbal products is challenging, and this is corroborated by our findings.

Several authors have advocated the use of DNA barcoding and metabarcoding in herbal product authentication and pharmacovigilance (Coghlan et al., 2012; Newmaster et al., 2013; Cheng et al., 2014; De Boer et al., 2015; Palhares et al., 2015; Ivanova et al., 2016), due to its cost effectiveness and ability to disclose plant species diversity within products. Our DNA metabarcoding results corroborate previous research that used metabarcoding to authenticate herbal products (Coghlan et al., 2012, 2015; Cheng et al., 2014; Ivanova et al., 2016; Veldman et al., 2017). In this study we confirm its applicability to test for presence of $V$. officinalis and simultaneously to detect substitution, adulteration and/or admixture of other Veronica species. Using DNA metabarcoding we found that only $15 \%$ of the products contained $V$. officinalis, whereas $62 \%$ of the products contained $V$. chamaedrys. Furthermore, we found that all the investigated herbal products contained other species not listed on the label. Limitations of DNA metabarcoding are its susceptibility to various factors, such as quality, processing state and product type of the extracted material, as well as several variables related to the methodological framework, such as DNA extraction procedures, primers, markers, amplification protocols for the library preparation sequencing platform, filtering, quality thresholds and chimera removal, and clustering thresholds.

Despite limitations of the methodology, our DNA metabarcoding results show that there is a need to study herbal products derived from traditional medicine, and to increase consumer confidence by advocating and promoting a higher standard of quality in herbal products. In recent years, the scientific community has been showing an increasing interest in finding adequate and comprehensive methodologies to investigate such complex products, focusing on their entire value chain, from the raw material to the product on the shelf.

\section{REFERENCES}

Afifi-Yazar, F. Ü., and Sticher, O. (1980). Verproside, a new iridoid glucoside from Veronica officinalis L. (Scrophulariaceae). Helv. Chim. Acta 63, 1905-1907. doi: 10.1002/hlca.19800630716

Albach, D. C., and Al-Gharaibeh, M. (2015). Systematics and biogeography of Veronica subg. Pentasepalae from the Levant. Willdenowia 45, 5-14. doi: 10.3372/wi.45.45101

Albach, D. C., and Chase, M. W. (2001). Paraphyly of Veronica (Veroniceae; Scrophulariaceae): evidence from the internal transcribed spacer (ITS) sequences of nuclear ribosomal DNA. J. Plant Res. 114, 9-18. doi: 10.1007/ PL00013971

Albach, D. C., and Chase, M. W. (2004). Incongruence in Veroniceae (Plantaginaceae): evidence from two plastid and a nuclear ribosomal DNA region. Mol. Phylogenet. Evol. 32, 183-197. doi: 10.1016/j.ympev.2003.12.001

Albach, D. C., Martínez-Ortega, M. M., and Chase, M. W. (2004). Veronica: parallel morphological evolution and phylogeography in the Mediterranean. Plant Syst. Evol. 246, 177-194. doi: 10.1007/s00606-004-0148-9

Albach, D. C., and Meudt, H. M. (2010). Phylogeny of Veronica in the Southern and Northern Hemispheres based on plastid, nuclear ribosomal and nuclear

\section{SUPPORTING INFORMATION}

Ion-Torrent amplicon read data is deposited in DRYAD doi: $10.5061 /$ dryad.606ks.

\section{AUTHOR CONTRIBUTIONS}

MI, HB, GC, and AR conceived the experiment. AR collected the material and carried out the molecular lab work and analysis. MP assisted with the molecular lab work. AM, LV, and GC carried out the phytochemical lab work and analyses. AR wrote the manuscript together with $\mathrm{HB}$ and $\mathrm{AB}$. All authors contributed to and approved the final version of the manuscript.

\section{FUNDING}

The authors acknowledge funding from the Romanian - EEA Research Programme operated by the MECS-ANCSI PO under the EEA Financial Mechanism 2009-2014 and project contract number 2SEE/2014.

\section{ACKNOWLEDGMENT}

B. L. Thorbek, Audun Schrøder-Nielsen, and Jarl Andreas Anmarkrud are acknowledged for help and assistance with the molecular laboratory analyses.

\section{SUPPLEMENTARY MATERIAL}

The Supplementary Material for this article can be found online at: http://journal.frontiersin.org/article/10.3389/fphar. 2017.00378/full\#supplementary-material

TABLE S6 | Veronica HTS reads and identified MOTUs per product at 99\% threshold.

low-copy DNA. Mol. Phylogenet. Evol. 54, 457-471. doi: 10.1016/j.ympev.2009. 09.030

Albach, D. C., Schönswetter, P., and Tribsch, A. (2006). Comparative phylogeography of the Veronica alpina complex in Europe and North America. Mol. Ecol. 15, 3269-3286. doi: 10.1111/j.1365-294X.2006.02980.x

Altschul, S. F., Gish, W., Miller, W., Myers, E. W., and Lipman, D. J. (1990). Basic local alignment search tool. J. Mol. Biol. 215, 403-410. doi: 10.1016/S00222836(05)80360-2

Atanasov, A. G., Waltenberger, B., Pferschy-Wenzig, E.-M., Linder, T., Wawrosch, C., Uhrin, P., et al. (2015). Discovery and resupply of pharmacologically active plant-derived natural products: a review. Biotechnol. Adv. 33, 1582-1614. doi: 10.1016/j.biotechadv.2015.08.001

Baker, D. A., Stevenson, D. W., and Little, D. P. (2012). DNA barcode identification of black cohosh herbal dietary supplements. J. AOAC Int. 95, 1023-1034. doi: 10.5740/jaoacint.11-261

Bansal, A., Chhabra, V., Rawal, R. K., and Sharma, S. (2014). Chemometrics: a new scenario in herbal drug standardization. J. Pharm. Anal. 4, 223-233. doi: 10.1016/j.jpha.2013.12.001

Barnes, J. (2003). Pharmacovigilance of herbal medicines. Drug Saf. 26, 829-851. doi: 10.2165/00002018-200326120-00001 
Baytop, T. (1984). Treatment with plants in Turkey. Istanbul. Univ. Publ. 3255:420. Bellia, G., and Pieroni, A. (2015). Isolated, but transnational: the glocal nature of Waldensian ethnobotany, Western Alps, NW Italy. J. Ethnobiol. Ethnomed. 11:37. doi: 10.1186/s13002-015-0027-1

Benson, D. A., Cavanaugh, M., Clark, K., Karsch-Mizrachi, I., Lipman, D. J., Ostell, J., et al. (2013). GenBank. Nucleic Acids Res. 41, D36-D42. doi: 10.1093/ nar/gks1195

Bertolazzi, P., Felici, G., and Weitschek, E. (2009). Learning to classify species with barcodes. BMC Bioinformatics 10:S7. doi: 10.1186/1471-2105-10S14-S7

Bickford, D., Lohman, D. J., Sodhi, N. S., Ng, P. K. L., Meier, R., Winker, K., et al. (2007). Cryptic species as a window on diversity and conservation. Trends Ecol. Evol. 22, 148-155. doi: 10.1016/j.tree.2006.11.004

Bombardelli, E. (1991). "Technologies for the processing of medicinal plants," in The Medicinal Plant Industry, ed. R. O. B. Wijesekera (Boca Raton, FL: CRC Press), 85-98.

Booker, A., Frommenwiler, D., Johnston, D., Umealajekwu, C., Reich, E., and Heinrich, M. (2014). Chemical variability along the value chains of turmeric (Curcuma longa): a comparison of nuclear magnetic resonance spectroscopy and high performance thin layer chromatography. J. Ethnopharmacol. 152, 292-301. doi: 10.1016/j.jep.2013.12.042

Booker, A., Johnston, D., and Heinrich, M. (2012). Value chains of herbal medicines-Research needs and key challenges in the context of ethnopharmacology. J. Ethnopharmacol. 140, 624-633. doi: 10.1016/j.jep.2012.01.039

Booker, A., Zhai, L., Gkouva, C., Li, S., and Heinrich, M. (2016). From traditional resource to global commodities:-a comparison of Rhodiola species using NMR spectroscopy-metabolomics and HPTLC. Front. Pharmacol. 7:254. doi: 10.3389/fphar.2016.00254

Buhk, N., Zhao, L., Li, H., and Albach, D. C. (2015). Molecular systematics and morphometrics in Veronica subsect. Canae (Plantaginaceae). Plant Syst. Evol. 301, 1967-1979. doi: 10.1007/s00606-015-1214-1

Burgess, K. S., Fazekas, A. J., Kesanakurti, P. R., Graham, S. W., Husband, B. C., Newmaster, S. G., et al. (2011). Discriminating plant species in a local temperate flora using the rbcL+matK DNA barcode. Methods Ecol. Evol. 2, 333-340. doi: 10.1111/j.2041-210X.2011.00092.x

CBOL Plant Working Group (2009). A DNA barcode for land plants. Proc. Natl. Acad. Sci. U.S.A. 106, 12794-12797. doi: 10.1073/pnas.09058 45106

Chen, S., Yao, H., Han, J., Liu, C., Song, J., Shi, L., et al. (2010). Validation of the ITS2 region as a novel DNA barcode for identifying medicinal plant species. PLoS ONE 5:e8613. doi: 10.1371/journal.pone.0008613

Chen, W., Zhang, C. K., Cheng, Y., Zhang, S., and Zhao, H. (2013). A comparison of methods for clustering 16S rRNA sequences into OTUs. PLoS ONE 8:e70837. doi: 10.1371/journal.pone.0070837

Cheng, X., Su, X., Chen, X., Zhao, H., Bo, C., Xu, J., et al. (2014). Biological ingredient analysis of traditional Chinese medicine preparation based on highthroughput sequencing: the story for Liuwei Dihuang Wan. Sci. Rep. 4:5147. doi: $10.1038 /$ srep05147

China Plant BOL Group (2011). Comparative analysis of a large dataset indicates that internal transcribed spacer (ITS) should be incorporated into the core barcode for seed plants. Proc. Natl. Acad. Sci. U.S.A. 108, 19641-19646. doi: 10.1073/pnas.1104551108

Coghlan, M. L., Haile, J., Houston, J., Murray, D. C., White, N. E., Moolhuijzen, P., et al. (2012). Deep sequencing of plant and animal DNA contained within traditional Chinese medicines reveals legality issues and health safety concerns. PLoS Genet. 8:e1002657. doi: 10.1371/journal.pgen.1002657

Coghlan, M. L., Maker, G., Crighton, E., Haile, J., Murray, D. C., White, N. E., et al. (2015). Combined DNA, toxicological and heavy metal analyses provides an auditing toolkit to improve pharmacovigilance of traditional Chinese medicine (TCM). Sci. Rep. 5:17457. doi: 10.1038/srep17475

Coissac, E., Hollingsworth, P. M., Lavergne, S., and Taberlet, P. (2016). From barcodes to genomes: extending the concept of DNA barcoding. Mol. Ecol. 25, 1423-1428. doi: $10.1111 / \mathrm{mec} .13549$

Cos, P., Vlietinck, A. J., Berghe, D. V., and Maes, L. (2006). Anti-infective potential of natural products: how to develop a stronger in vitro 'proof-of-concept'. J. Ethnopharmacol. 106, 290-302. doi: 10.1016/j.jep.2006.04.003

Crişan, G., Tamas, M., Garbacki, N., and Angenot, L. (2001). Criterii de differentiere a unor specii de Veronica. Farmacia 49, 67-73.
Crişan, G., Tămaş, M., Miclăuş, V., Krausz, T., and Sandor, V. (2007). A comparative study of some Veronica species. Rev. Med. Chir. Soc. Med. Nat. Iasi 111, 280-284.

Crişan, G., Vlase, L., Balica, G., Muntean, D., Ştefănescu, C., Păltinean, R., et al. (2010). LC/MS analysis of aucubin and catalpol of some Veronica species. Farmacia 58, 237-242.

Crişan, G., Vlase, L., Crişan, O., and Ichim, M. (2011). Comparative phytochemical study on Veronica officinalis L. and Veronica chamaedrys L. Planta Med. 77:PL14. doi: 10.1055/s-0031-1282663

De Boer, H. J., Ichim, M. C., and Newmaster, S. G. (2015). DNA barcoding and pharmacovigilance of herbal medicines. Drug Saf. 38, 611-620. doi: 10.1007/ s40264-015-0306-8

Doyle, J. J., and Doyle, J. L. (1987). A rapid DNA isolation procedure for small quantities of fresh leaf tissue. Phytochem. Bull. 19, 11-15.

EDQM - Council of Europe. (2014). European Pharmacopoeia, 8th Edn. Strasbourg: Council of Europe.

European Medicine Agency [EMA] (2006). EMEA/CVMP/815/00 - Guideline on Specifications: Test Procedures and Acceptance Criteria for Herbal Substances, Herbal Preparations and Herbal Medicinal Products. London: EMA.

Farah, M. H., Olsson, S., Bate, J., Lindquist, M., Edwards, R., Simmonds, M. S., et al. (2006). Botanical nomenclature in pharmacovigilance and a recommendation for standardisation. Drug Saf. 29, 1023-1029. doi: 10.2165/ 00002018-200629110-00002

Fazekas, A. J., Kesanakurti, P. R., Burgess, K. S., Percy, D. M., Graham, S. W., Barrett, S. C. H., et al. (2009). Are plant species inherently harder to discriminate than animal species using DNA barcoding markers? Mol. Ecol. Resour. 9, 130-139. doi: 10.1111/j.1755-0998.2009.02652.x

Fujita, T., Sezik, E., Tabata, M., Yesilada, E., Honda, G., Takeda, Y., et al. (1995). Traditional medicine in Turkey VII. Folk medicine in middle and west Black Sea regions. Econ. Bot. 49, 406-422. doi: 10.1007/BF02863092

Gertsch, J. (2009). How scientific is the science in ethnopharmacology? Historical perspectives and epistemological problems. J. Ethnopharmacol. 122, 177-183. doi: 10.1016/j.jep.2009.01.010

Ghorbani, A., Gravendeel, B., Selliah, S., Zarre, S., and de Boer, H. J. (2016). DNA barcoding of tuberous Orchidoideae: a resource for identification of orchids used in Salep. Mol. Ecol. Resour. 17, 342-352. doi: 10.1111/1755-0998.12615

Gilbert, N. (2011). Regulations: herbal medicine rule book. Nature 480, S98-S99. doi: $10.1038 / 480598$ a

Gründemann, C., Garcia-Käufer, M., Sauer, B., Stangenberg, E., Könczöl, M., Merfort, I., et al. (2013). Traditionally used Veronica officinalis inhibits proinflammatory mediators via the NF- $\mathrm{B}$ signalling pathway in a human lung cell line. J. Ethnopharmacol. 145, 118-126. doi: 10.1016/j.jep.2012.10.039

Harput, U. S., Nagatsu, A., Ogihara, Y., and Saracoglu, I. (2014). Iridoid glucosides from Veronica pectinata var. glandulosa. Z. Naturforsch. C 58, 481-484.

Harput, U. S., Saracoglu, I., Inoue, M., and Ogihara, Y. (2002a). Anti-inflammatory and cytotoxic activities of five Veronica species. Biol. Pharm. Bull. 25, 483-486. doi: 10.1248/bpb.25.483

Harput, U. S., Saracoglu, I., Inoue, M., and Ogihara, Y. (2002b). Phenylethanoid and iridoid glycosides from Veronica persica. Chem. Pharm. Bull. 50, 869-871. doi: $10.1248 /$ cpb.50.869

Hebert, P. D. N., Cywinska, A., Ball, S. L., and deWaard, J. R. (2003). Biological identifications through DNA barcodes. Proc. R. Soc. Lond. B Biol. Sci. 270, 313-321. doi: 10.1098/rspb.2002.2218

Hebert, P. D. N., Stoeckle, M. Y., Zemlak, T. S., and Francis, C. M. (2004). Identification of birds through DNA barcodes. PLoS Biol. 2:e312. doi: 10.1371/ journal.pbio.0020312

Heinrich, M. (2010). Ethnopharmacology in the 21st century - grand challenges. Front. Pharmacol. 1:8. doi: 10.3389/fphar.2010.00008

Heubl, G. (2010). New aspects of DNA-based authentication of Chinese medicinal plants by molecular biological techniques. Planta Med. 76, 1963-1974. doi: 10.1055/s-0030- 1250519

Hollingsworth, P. M., Graham, S. W., and Little, D. P. (2011). Choosing and using a plant DNA barcode. PLoS ONE 6:e19254. doi: 10.1371/journal.pone.0019254

Hollingsworth, P. M., Li, D.-Z., Bank, M., van der, and Twyford, A. D. (2016). Telling plant species apart with DNA: from barcodes to genomes. Philos. Trans. R. Soc. B Biol. Sci. 371:20150338. doi: 10.1098/rstb.2015.0338

Ichim, M. C., Raclariu, A. C., Paramon, P. P., and Toth, E. T. (2011). Biodiversity assessment of Veronica sp. in Romania for their characterization, preservation 
and sustainable use in pharmacognosy. Planta Med. 77, L26. doi: 10.1055/s0031-1282675

Ignjatović, Đ., Živković, J., Tovilović, G., Šavikin, K., Tomić, M., Maksimović, Z., et al. (2015). Evaluation of angiogenic and neuroprotective potential of different extracts from three Veronica species. Front. Life Sci. 8:107-116. doi: 10.1080/21553769.2014.998297

Ivancheva, S., and Stantcheva, B. (2000). Ethnobotanical inventory of medicinal plants in Bulgaria. J. Ethnopharmacol. 69, 165-172. doi: 10.1016/S03788741(99)00129-4

Ivanova, N. V., Kuzmina, M. L., Braukmann, T. W. A., Borisenko, A. V., and Zakharov, E. V. (2016). Authentication of herbal supplements using nextgeneration sequencing. PLOS ONE 11:e0156426. doi: 10.1371/journal.pone. 0156426

Jensen, S. R., Albach, D. C., Ohno, T., and Grayer, R. J. (2005). Veronica: iridoids and cornoside as chemosystematic markers. Biochem. Syst. Ecol. 33, 1031-1047. doi: 10.1016/j.bse.2005.03.001

Jiang, Y., David, B., Tu, P., and Barbin, Y. (2010). Recent analytical approaches in quality control of traditional Chinese medicines-a review. Anal. Chim. Acta 657, 9-18. doi: 10.1016/j.aca.2009.10.024

Jukes, T. H., and Cantor, C. R. (1969). "Evolution of protein molecules," in Mammalian Protein Metabolism, ed. H. N. Munro (New York, NY: Academic Press), 21-132. doi: 10.1016/b978-1-4832-3211-9.50009-7

Kathe, W., Honnef, S., and Heym, A. (2003). Medicinal and Aromatic Plants in Albania, Bosnia-Herzegovina, Bulgaria, Croatia and Romania: A Study of the Collection of and Trade in Medicinal and Aromatic Plants (MAPs), Relevant Legislation and the Potential of MAP Use for Financing Nature Conservation and Protected Areas. Bonn: Federal Agency for Nature Conservation.

Kimura, M. (1980). A simple method for estimating evolutionary rates of base substitutions through comparative studies of nucleotide sequences. J. Mol. Evol. 16, 111-120. doi: 10.1007/BF01731581

Kool, A., de Boer, H. J., Krüger, Å., Rydberg, A., Abbad, A., Björk, L., et al. (2012). Molecular identification of commercialized medicinal plants in southern Morocco. PLoS ONE 7:e39459. doi: 10.1371/journal.pone.0039459

Kress, W. J., and Erickson, D. L. (2007). A two-locus global DNA barcode for land plants: the coding rbcL gene complements the non-coding trnH-psbA spacer region. PLoS ONE 2:e508. doi: 10.1371/journal.pone.0000508

Kress, W. J., Erickson, D. L., Jones, F. A., Swenson, N. G., Perez, R., Sanjur, O., et al. (2009). Plant DNA barcodes and a community phylogeny of a tropical forest dynamics plot in Panama. Proc. Natl. Acad. Sci. U.S.A. 106, 18621-18626. doi: 10.1073/pnas.0909820106

Kress, W. J., Erickson, D. L., Swenson, N. G., Thompson, J., Uriarte, M., and Zimmerman, J. K. (2010). Advances in the use of DNA barcodes to build a community phylogeny for tropical trees in a puerto rican forest dynamics plot. PLoS ONE 5:e15409. doi: 10.1371/journal.pone.0015409

Küpeli, E., Harput, U. S., Varel, M., Yesilada, E., and Saracoglu, I. (2005). Bioassay-guided isolation of iridoid glucosides with antinociceptive and antiinflammatory activities from Veronica anagallis-aquatica L. J. Ethnopharmacol. 102, 170-176. doi: 10.1016/j.jep.2005.05.042

Lahaye, R., Bank, M., van der, Bogarin, D., Warner, J., Pupulin, F., et al. (2008). DNA barcoding the floras of biodiversity hotspots. Proc. Natl. Acad. Sci. U.S.A. 105, 2923-2928. doi: 10.1073/pnas.0709936105

Lammers, Y., Peelen, T., Vos, R. A., and Gravendeel, B. (2014). The HTS barcode checkerpipeline, a tool for automated detection of illegally traded species from high-throughput sequencing data. BMC Bioinformatics 15:44. doi: 10.1186/ 1471-2105-15-44

Larsson, A. (2014). AliView: a fast and lightweight alignment viewer and editor for large datasets. Bioinformatics 30, 3276-3278. doi: 10.1093/bioinformatics/ btu531

Leonti, M., and Casu, L. (2013). Traditional medicines and globalization: current and future perspectives in ethnopharmacology. Front. Pharmacol. 4:92. doi: 10.3389/fphar.2013.00092

Leporatti, M. L., and Ivancheva, S. (2003). Preliminary comparative analysis of medicinal plants used in the traditional medicine of Bulgaria and Italy. J. Ethnopharmacol. 87, 123-142. doi: 10.1016/S0378-8741(03) 00047-3

Leyel, C. (1937). Herbal Delights: Tisanes, Syrups, Confections, Electuaries, Robs, Juleps, Vinegars, and Conserve. London: Faber \& Faber.
Li, W., and Godzik, A. (2006). CD-HIT: a fast program for clustering and comparing large sets of protein or nucleotide sequences. Bioinformatics 22, 1658-1659. doi: 10.1093/bioinformatics/btl158

Little, D. P. (2014). Authentication of Ginkgo biloba herbal dietary supplements using DNA barcoding. Genome 57, 513-516. doi: 10.1139/gen-2014-0130

Little, D. P., and Jeanson, M. L. (2013). DNA barcode authentication of Saw Palmetto herbal dietary supplements. Sci. Rep. 3:3518. doi: 10.1038/srep03518

Loman, N. J., Misra, R. V., Dallman, T. J., Constantinidou, C., Gharbia, S. E., Wain, J., et al. (2012). Performance comparison of benchtop high-throughput sequencing platforms. Nat. Biotechnol. 30, 434-439. doi: 10.1038/nbt.2198

Mabberley, D. J. (2008). Mabberley's Plant-Book: A Portable Dictionary of Plants, Their Classifications and Uses. Cambridge: Cambridge University Press.

Meier, R., Shiyang, K., Vaidya, G., Ng, P. K. L., and Hedin, M. (2006). DNA barcoding and taxonomy in Diptera: a tale of high intraspecific variability and low identification success. Syst. Biol. 55, 715-728. doi: 10.1080/ 10635150600969864

Meier, R., Zhang, G., Ali, F., and Zamudio, K. (2008). The use of mean instead of smallest interspecific distances exaggerates the size of the "barcoding gap" and leads to misidentification. Syst. Biol. 57, 809-813. doi: 10.1080/ 10635150802406343

Menković, N., Šavikin, K., Tasić, S., Zdunić, G., Stešević, D., Milosavljević, S., et al. (2011). Ethnobotanical study on traditional uses of wild medicinal plants in Prokletije Mountains (Montenegro). J. Ethnopharmacol. 133, 97-107. doi: 10.1016/j.jep.2010.09.008

Meyer, C. P., and Paulay, G. (2005). DNA barcoding: error rates based on comprehensive sampling. PLoS Biol. 3:e422. doi: 10.1371/journal.pbio.0030422

Mocan, A., Vlase, L., Arsene, A. L., Vodnar, D., Bischin, C., Silaghi-Dumitrescu, R., et al. (2015a). HPLC/MS analysis of caffeic and chlorogenic acids from three Romanian Veronica species and their antioxidant and antimicrobial proprieties. Farmacia 63, 890-896.

Mocan, A., Vodnar, D. C., Vlase, L., Crişan, O., Gheldiu, A. M., and Crişan, G. (2015b). Phytochemical characterization of Veronica officinalis L., V. teucrium L. and $V$. orchidea Crantz from Romania and their antioxidant and antimicrobial properties. Int. J. Mol. Sci. 16, 21109-21127. doi: 10.3390/ ijms160921109

Newmaster, S. G., Grguric, M., Shanmughanandhan, D., Ramalingam, S., and Ragupathy, S. (2013). DNA barcoding detects contamination and substitution in North American herbal products. BMC Med. 11:222. doi: 10.1186/17417015-11-222

Nikolova, M. (2011). Screening of radical scavenging activity and polyphenol content of Bulgarian plant species. Pharmacogn. Res. 3, 256-259. doi: 10.4103/ 0974-8490.89746

Novak, J., Grausgruber-Gröger, S., and Lukas, B. (2007). DNA-based authentication of plant extracts. Food Res. Int. 40, 388-392. doi: 10.1016/j.foodres.2006.10.015

Ouarghidi, A., Powell, B., Martin, G. J., de Boer, and Abbad, A. (2012). Species substitution in medicinal roots and possible implications for toxicity of herbal remedies in Morocco. Econ. Bot. 66, 370-382. doi: 10.1007/s12231-0129215-2

Palhares, R. M., Drummond, M. G., Brasil, B., dos, S. A. F., Cosenza, G. P., Brandão, M., et al. (2015). Medicinal plants recommended by the World Health Organization: DNA barcode identification associated with chemical analyses guarantees their quality. PLoS ONE 10:e0127866. doi: 10.1371/journal.pone. 0127866

Pawluczyk, M., Weiss, J., Links, M. G., Egaña Aranguren, M., Wilkinson, M. D., and Egea-Cortines, M. (2015). Quantitative evaluation of bias in PCR amplification and next-generation sequencing derived from metabarcoding samples. Anal. Bioanal. Chem. 407, 1841-1848. doi: 10.1007/s00216-014-8435-y

Puillandre, N., Lambert, A., Brouillet, S., and Achaz, G. (2012). ABGD, Automatic Barcode Gap Discovery for primary species delimitation. Mol. Ecol. 21, 1864-1877. doi: 10.1111/j.1365-294X.2011.05239.x

Rach, J., DeSalle, R., Sarkar, I. N., Schierwater, B., and Hadrys, H. (2008). Characterbased DNA barcoding allows discrimination of genera, species and populations in Odonata. Proc. R. Soc. Lond. B Biol. Sci. 275, 237-247. doi: 10.1098/rspb.2007. 1290

Raclariu, A. C., Paltinean, R., Vlase, L., Labarre, A., Manzanilla, V., Ichim, M. C., et al. (2017). Comparative authentication of Hypericum perforatum herbal 
products using DNA metabarcoding, TLC and HPLC-MS. Sci. Rep. 7:1291. doi: 10.1038/s41598-017-01389-w

Ratnasingham, S., and Hebert, P. D. N. (2013). A DNA-Based registry for all animal species: the barcode index number (BIN) system. PLoS ONE 8:e66213. doi: 10.1371/journal.pone. 0066213

Ríos, J. L., and Recio, M. C. (2005). Medicinal plants and antimicrobial activity. J. Ethnopharmacol. 100, 80-84. doi: 10.1016/j.jep.2005.04.025

Rios, J. L., Recio, M. C., and Villar, A. (1988). Screening methods for natural products with antimicrobial activity: a review of the literature. J. Ethnopharmacol. 23, 127-149. doi: 10.1016/0378-8741(88)90001-3

Salipante, S. J., Kawashima, T., Rosenthal, C., Hoogestraat, D. R., Cummings, L. A., Sengupta, D. J., et al. (2014). Performance comparison of illumina and ion torrent next-generation sequencing platforms for $16 \mathrm{~S}$ rRNA-based bacterial community profiling. Appl. Environ. Microbiol. 80, 7583-7591. doi: 10.1128/ AEM.02206-14

Saracoglu, I., and Harput, U. S. (2012). In vitro cytotoxic activity and structure activity relationships of iridoid glucosides derived from Veronica species. Phytother. Res. 26, 148-152. doi: 10.1002/ptr.3546

Saracoglu, I., Harput, U. S., Inoue, M., and Ogihara, Y. (2002). New phenylethanoid glycosides from Veronica pectinata var. glandulosa and their free radical scavenging activities. Chem. Pharm. Bull. 50, 665-668. doi: 10.1248/cpb.50.665

Saslis-Lagoudakis, C. H., Bruun-Lund, S., Iwanycki, N. E., Seberg, O., Petersen, G., Jäger, A. K., et al. (2015). Identification of common horsetail (Equisetum arvense L.; Equisetaceae) using thin layer chromatography versus DNA barcoding. Sci. Rep. 5:11942. doi: 10.1038/srep11942

Scarlat, M., Şandor, V., Tămaş, M., and Cuparencu, B. (1985). Experimental antiulcer activity of Veronica officinalis L. extracts. J. Ethnopharmacol. 13, 157-163. doi: 10.1016/0378-8741(85)90003-0

Schmieder, R., and Edwards, R. (2011). Quality control and preprocessing of metagenomic datasets. Bioinformatics 27, 863-864. doi: 10.1093/ bioinformatics/btr026

Seethapathy, G. S., Ganesh, D., Kumar, J. U. S., Senthilkumar, U., Newmaster, S. G., Ragupathy, S., et al. (2014). Assessing product adulteration in natural health products for laxative yielding plants, Cassia, Senna, and Chamaecrista, in Southern India using DNA barcoding. Int. J. Legal Med. 129, 693-700. doi: $10.1007 / \mathrm{s} 00414-014-1120-\mathrm{z}$

Shaw, D., Graeme, L., Pierre, D., Elizabeth, W., and Kelvin, C. (2012). Pharmacovigilance of herbal medicine. J. Ethnopharmacol. 140, 513-518. doi: $10.1016 /$ j.jep.2012.01.051

Smith, M. A., Fisher, B. L., and Hebert, P. D. N. (2005). DNA barcoding for effective biodiversity assessment of a hyperdiverse arthropod group: the ants of Madagascar. Philos. Trans. R. Soc. Lond. B Biol. Sci. 360, 1825-1834. doi: 10.1098/rstb.2005.1714

Sonibare, M. A., Armagan, M., Özgökce, F., Yaprak, A. E., Mayland-Quellhorst, E., and Albach, D. C. (2014). Analysis of taxonomic and geographic patterns of Turkish Veronica orientalis using nuclear and plastid DNA and morphological data. Plant Syst. Evol. 300, 645-664. doi: 10.1007/s00606-013-0909-4

Sõukand, R., Quave, C. L., Pieroni, A., Pardo-de-Santayana, M., Tardío, J., Kalle, R., et al. (2013). Plants used for making recreational tea in Europe: a review based on specific research sites. J. Ethnobiol. Ethnomed. 9:58. doi: 10.1186/1746-42699-58

Steinmann, D., and Ganzera, M. (2011). Recent advances on HPLC/MS in medicinal plant analysis. J. Pharm. Biomed. Anal. 55, 744-757. doi: 10.1016/j. jpba.2010.11.015

Stoeckle, M. Y., Gamble, C. C., Kirpekar, R., Young, G., Ahmed, S., and Little, D. P. (2011). Commercial teas highlight plant DNA barcode identification successes and obstacles. Sci. Rep. 1:42. doi: 10.1038/srep00042

Stucky, B. J. (2012). SeqTrace: a graphical tool for rapidly processing DNA sequencing chromatograms. J. Biomol. Tech. 23, 90-93. doi: 10.7171/jbt.122303-004

Su, B.-N., Zhu, Q.-X., and Jia, Z.-J. (1999). Aquaticol, a novel bis-sesquiterpene from Veronica anagallis-aquatica. Tetrahedron Lett. 40, 357-358. doi: 10.1016/ S0040-4039(98)02303-X

Sun, Y., Skinner, D. Z., Liang, G. H., and Hulbert, S. H. (1994). Phylogenetic analysis of Sorghum and related taxa using internal transcribed spacers of nuclear ribosomal DNA. Theor. Appl. Genet. 89, 26-32. doi: 10.1007/ BF00226978
Taberlet, P., Coissac, E., Pompanon, F., Brochmann, C., and Willerslev, E. (2012). Towards next-generation biodiversity assessment using DNA metabarcoding. Mol. Ecol. 21, 2045-2050. doi: 10.1111/j.1365-294X.2012. 05470.x

Tamas, M., Rosca, M., and Scarlat, M. A. (1984). Studiul fitochimic al plantei Veronica officinalis L. Clujul Med. 47, 169-172.

Tamura, K., Stecher, G., Peterson, D., Filipski, A., and Kumar, S. (2013). MEGA6: molecular evolutionary genetics analysis version 6.0. Mol. Biol. Evol. 30, 2725-2729. doi: 10.1093/molbev/mst197

Taskova, R., Peev, D., and Handjieva, N. (2002). Iridoid glucosides of the genus Veronica s.l. and their systematic significance. Plant Syst. Evol. 231, 1-17. doi: $10.1007 / \mathrm{s} 006060200008$

Taskova, R. M., Albach, D. C., and Grayer, R. J. (2004). Phylogeny of Veronica - a combination of molecular and chemical evidence. Plant Biol. 6, 673-682. doi: 10.1055/s-2004-830330

Techen, N., Parveen, I., Pan, Z., and Khan, I. A. (2014). DNA barcoding of medicinal plant material for identification. Curr. Opin. Biotechnol. 25, 103-110. doi: 10.1016/j.copbio.2013.09.010

Veldman, S., Gravendeel, B., Otieno, J. N., Lammers, Y., Duijm, E., Nieman, A., et al. (2017). High-throughput sequencing of African chikanda cake highlights conservation challenges in orchids. Biodivers. Conserv. 215, 1-18.

Verpoorte, R. (2008). Setting standards: diabetes. J. Ethnopharmacol. 115, 161-162. doi: $10.1016 /$ j.jep.2007.10.035

Vogl, S., Picker, P., Mihaly-Bison, J., Fakhrudin, N., Atanasov, A. G., Heiss, E. H., et al. (2013). Ethnopharmacological in vitro studies on Austria's folk medicine-an unexplored lore in vitro anti-inflammatory activities of 71 Austrian traditional herbal drugs. J. Ethnopharmacol. 149, 750-771. doi: 10. 1016/j.jep.2013.06.007

Wagstaff, S. J., and Garnock-Jones, P. J. (1998). Evolution and biogeography of the Hebe complex (Scrophulariaceae) inferred from ITS sequences. N. Z. J. Bot. 36, 425-437. doi: 10.1080/0028825X.1998.9512581

Walker, K. M., and Applequist, W. L. (2012). Adulteration of selected unprocessed botanicals in the U.S. retail herbal trade. Econ. Bot. 66, 321-327. doi: 10.1007/ s12231-012-9211-6

Wallace, L. J., Boilard, S. M. A. L., Eagle, S. H. C., Spall, J. L., Shokralla, S., and Hajibabaei, M. (2012). DNA barcodes for everyday life: routine authentication of natural health products. Food Res. Int. 49, 446-452. doi: 10.1016/j.foodres. 2012.07.048

White, T. J., Bruns, T., Lee, S., and Taylor, J. W. (1990). "Amplification and direct sequencing of fungal ribosomal RNA genes for phylogenetics," in $P C R$ Protocols: A Guide to Methods and Applications, eds M. A. Innis, D. H. Gelfand, J. J. Sninsky, and T. J. White (New York, NY: Academic Press), $315-322$.

Wiemers, M., and Fiedler, K. (2007). Does the DNA barcoding gap exist? - a case study in blue butterflies (Lepidoptera: Lycaenidae). Front. Zool. 4:8. doi: 10.1186/1742-9994-4-8

World Health Organization (2013). WHO Traditional Medicine Strategy: 20142023. Geneva: World Health Organization.

Yang, Z., and Rannala, B. (2017). Bayesian species identification under the multispecies coalescent provides significant improvements to DNA barcoding analyses. Mol. Ecol. 26, 3028-3036. doi: 10.1111/mec.14093

Zlatković, B. K., Bogosavljević, S. S., Radivojević, A. R., and Pavlović, M. A. (2014). Traditional use of the native medicinal plant resource of Mt. Rtanj (Eastern Serbia): ethnobotanical evaluation and comparison. J. Ethnopharmacol. 151, 704-713. doi: 10.1016/j.jep.2013.11.037

Conflict of Interest Statement: The authors declare that the research was conducted in the absence of any commercial or financial relationships that could be construed as a potential conflict of interest.

Copyright (c) 2017 Raclariu, Mocan, Popa, Vlase, Ichim, Crisan, Brysting and de Boer. This is an open-access article distributed under the terms of the Creative Commons Attribution License (CC BY). The use, distribution or reproduction in other forums is permitted, provided the original author(s) or licensor are credited and that the original publication in this journal is cited, in accordance with accepted academic practice. No use, distribution or reproduction is permitted which does not comply with these terms. 